\title{
Matriks dan Pengukuran Terhadap Kinerja Tata Kelola Teknologi Informasi
}

\author{
Maniah* $^{* 1}$, Shiyami Milwandhari ${ }^{2}$ \\ ${ }^{1,2}$ Politeknik Pos Indonesia: Jl. Sariasih No. 54 Bandung 40151, Telp. (022-2009562) \\ ${ }^{1,2}$ Major of Informatics Management, Politeknik Pos Indonesia, Bandung \\ e-mail:*11maniah@poltekpos.ac.id, ${ }^{2}$ shiyami@poltekpos.ac.id
}

\begin{abstract}
Abstrak
Tata Kelola Teknologi Informasi (TI) adalah proses yang memastikan penggunaan TI yang efektif dan efisien dalam memungkinkan organisasi untuk mencapai tujuannya (dari Gerrard, 2010) dalam[1].Makalah ini bertujuan untuk menetapkan matriks tata kelola TI dan mengukur kinerja tata kelola TI yang diterapkan pada suatu organisasi.Penelitian ini dilakukan dengan carastudi kasus pada suatu organisasi. Metode penelitian yang digunakan adalah dengan pendekatan metode kualitatif, dengan cara penyebaran kuesioner kepada responden, kemudian hasil kuesioner diolah menggunakan template "IT Governance one page" dan menilai kinerja tata kelola TI[2].Hasil penelitian ini menunjukkan bahwa susunan matriks tata kelola TI di PT. Pos Indonesia adalah Hibrida, yang menjelaskan bahwa Prinsip IT, Arsitektur TI, Infrastruktur TI dan Investasi TI lebih tersebar ke berbagai divisi. Hasil evaluasi kinerja tata kelola TI di PT. Pos Indonesia menunjukkan bahwa posisinya di bawah rata-rata dengan nilai kinerja 65,6 (kisaran 20 - 90, dengan nilai rata-rata adalah 69)[2]. Kontribusi hasil penelitian ini adalah untuk membantu manajemen dalam mengambil keputusan terkait keberlanjutan tata kelola TI di PT. Pos Indonesia.
\end{abstract}

Kata kunci-Tata Kelola TI, Kinerja, Matriks, Hibrida

\begin{abstract}
Information Technology Governance (IT) is a process that ensures the effective and efficient use of IT in enabling organizations to achieve their goals (from Gerrard, 2010) in [1]. This paper aims to establish an IT governance matrix and measure the performance of IT governance applied to an organization. This research was conducted by means of case studies in an organization. The research method used is a qualitative method approach, by distributing questionnaires to respondents, then the results of the questionnaire are processed using the "IT Governance one page" template and assessing IT governance performance [2]. The results of this study indicate that the composition of the IT governance matrix at PT. Pos Indonesia is Hybrid, which explains that IT Principles, IT Architecture, IT Infrastructure and IT Investment are more spread to various divisions. The results of the evaluation of IT governance performance at PT. Pos Indonesia shows that its position is below average with a performance value of 65.6 (range 20 - 90, with an average value of 69)[2]. The contribution of the results of this study is to assist management in making decisions related to the sustainability of IT governance at PT. Pos Indonesia.
\end{abstract}

Keywords—IT Governance, performance, matrix, hybrid 


\section{PENDAHULUAN}

$\mathrm{T}$ ata kelola teknologi informasi (TI) saat ini sudah merupakan suatu yang prioritas serta telah menjadi perhatian penting untuk bisnisdalam perusahaan [3], [4]. Tata kelola TI bertujuan untuk mencapai tujuan perusahaan dengan baik dan dianggap penting dalam suatu organisasi untuk menentukan dan mengendalikan bagaimana organisasi menggunakan teknologi informasi untuk mendukung strategi bisnisnya [5]. Proses pembentukan model tata kelola TI terkait dengan tugas, tanggung jawab dan hubungan proses terbentuk karena keinginan, penentuan kepemilikan dan akuntabilitas, adanya keterbukaan dan implementasi proses umum yang prinsipnya jelas [6]. Dalam upaya penerapan tata kelola TI dalam perusahaan, diperlukan sebuah tatanan pekerjaan serta metode monitoring dan evaluasi terhadap tata kelola TI tersebut [7].

Ruang lingkup atau domain tata kelola TI meliputi: prinsip TI, strategi infrastruktur TI, arsitektur TI, kebutuhan aplikasi bisnis, serta investasi dan prioritas TI [8]. Salah satu bagian dari ruang lingkup tata kelola TI yang merupakan kebutuhan perusahaan adalah investasi TI. Investasi TI dirancang berdasarkan perkiraan bahwa perusahaan memiliki potensi untuk merampingkan proses bisnis dan keunggulan perusahaan untuk menjadi kompetitif [9]. Munculnya investasi TI adalah karena kehadiran TI adalah wajib, dampak dan konsekuensi dari masalah yang ada (adanya potensi kerugian), dan karena mereka ingin meningkatkan kinerja dalam bentuk peningkatan keuntungan perusahaan [8].

Tata kelola TI harus selaras dengan tujuan bisnis perusahaan, dengan cara melakukan penilaian atas tingkat kematangan keselarasan strategis sebagai alat untuk menilai tingkat keselarasan strategi TI dengan strategi bisnis [10]. Jenis bisnis dapat berupa finansial ataupun nonfinansial. Pada perusahaan nonfinansial, kita dapat melihat secara signifikan ukuran kinerja perusahaan dengan melibatkan hubungan antara peranan pimpinan, teknologi modern dan kinerja penggunaan non-finansial [11]. Penelitian ini akan menunjukkan matriks pengukuran dan nilai kinerja tata kelola TI pada perusahaan / industri logistik, yaitu PT. Pos Indonesia, dengan cara melakukan pengukuran terhadap domain tata kelola TI (dari Peter Wiell and Jeanne W. Ross, 2004) yang terdapat dalam [1].

Beberapa penelitian sebelumnya yang sudah dilakukan yaitu penelitian yang bertujuan untuk mengukur tata kelola teknologi informasi di lembaga keuangan yang beroperasi di Brasil [2], untuk mengetahui pengaruh ukuran kinerja non-finansial (NF) terhadap kinerja individu melalui inovasi dalam organisasi yang terdaftar di Bursa Efek Indonesia, variabel yang digunakan ada 3 (tiga) yaitu: NFPM (NF performance measures), inovasi, dan kinerja manajerial [12], kemudian secara empiris memvalidasi tata kelola IT yang merupakan anteseden penting dari kemampuan TI, yang pada gilirannya menghasilkan peningkatan kinerjaperusahaan [13].

\section{METODOLOGI PENELITIAN}

Penelitian ini menggunakan metode penelitian kualitatif yang dilakukan dengan cara studi kasus pada perusahaan yang mengimplementasikan tata kelola teknologi informasi. Tahapan dalam penelitian ini dilakukan dengan beberapa tahap, yaitu: (1) introduction, tahap ini merupakan tahap pendefinisian konsep tata kelola TI. Tata kelola teknologi informasi merupakan upaya perusahaan untuk menempatkan fungsi teknologi informasi sebagai mitra strategi dalam menangani bisnis perusahaan. Fungsi teknologi informasi dan fungsi bisnis perusahaan harus selaras dalam rangka upaya untuk mencapai visi perusahaan; (2) Melakukan studi kasus, tahap ini melakukan studi kasus - menetapkan organisasi sebagai objek penelitian untuk memetakan matriks pengaturan tata kelola TI; (3) Penyebaran kuesioner dan pengolahan 
data hasil kuesioner.Tahap ini mengirimkan daftar kuesioneryangmenggunakan template $I T$ Governance Performance yang bertujuan untuk mendapatkan masukan awal dari pengguna sistem sebagai alat untuk pengukuran kinerja tata kelola TI untuk perusahaan atau unit bisnis. Ada 2 (dua) informasi yang akan disampaikan melalui hasil kuesioner, yaitu: 1. Seberapa pentingkah hasil tata kelola TI pada skala 1 (tidak penting) hingga 5 (sangat penting); 2. Apa pengaruh tata kelola TI dalam bisnis pada ukuran keberhasilan dari skala 1 (tidak berhasil) hingga 5 (sangat sukses). Peneliti menggunakan template ini karena dapat digunakan untuk mengukur kinerja tata kelola TI secara subyektif, ini dapat dilihat dari semua domain keputusan. Selain itu, template ini dapat memberikan panduan tentang cara mendesain, berkomunikasi, dan memperbarui cara TI menciptakan nilai bisnis; (4) finding - conclusion, tahap ini mengolah data hasil kuesioner dari responden, dan menyimpulkan temuan-temuan yang ada, hasil dari tahap ini menggambarkan matriks tata kelola TI dan menyimpulkan nilai kinerja tata kelola TI.

Secara keseluruhan tahapan penelitian ini dapat diilustrasikan dalam Gambar 1 berikut ini:

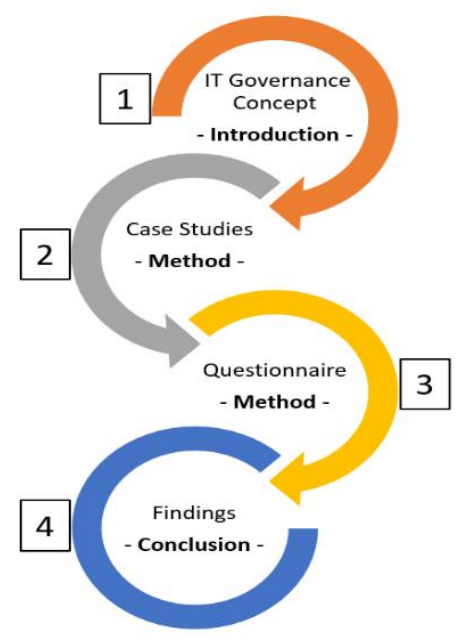

Gambar 1. Tahap Penelitian

\section{HASIL ANALYSIS STUDI KASUS}

Penelitian ini yang bertujuan untuk menentukan matriks regulasi tata kelola TI dan menilai nilai kinerja tata kelola TI yang diterapkan di perusahaan PT. Pos Indonesia. Sebagai sumber data yang digunakan untuk menampilkan hasil penelitian ini adalah: pertama, data dan informasi terkait dengan proses bisnis dalam menerapkan tata kelola TI perusahaan, dan yang kedua adalah data dari kuesioner yang didistribusikan kepada manajer eksekutif dan pemimpin unit bisnis, dimana unit bisnis yang terlibat adalah unit bisnis yang merupakan anak perusahaan dari PT. Pos Indonesia.

\section{A. Matriks Tata Kelola Teknologi Informasi pada PT. Pos Indonesia}

Pengembangan bisnis Perusahaan Pos Indonesia berasal dari bisnis inti yang terdiri dari: post express, surat pos biasa (standar), paket pos, pos kilat khusus, express mail service (EMS), surat pos iklan, dan filateli. Kemudian berkembang menjadi Jasa Keuangan, terdiri dari: pascabayar, wesel pos, rekening pos, distribusi dana, dan chanel bank. Selain itu, Pos Indonesia juga merambah ke Pos Logistik Bisnis "PosLog". Tujuan "PosLog" adalah untuk menyediakan solusi layanan terintegrasi untuk masalah logistik yang meliputi Pergudangan, Pengangkutan 
dan Pengangkutan Barang berdasarkan konsep Manajemen Rantai Pasok.Saat ini PT. Pos Indonesia telah mengembangkan bisnis di sektor properti.

Peranan teknologi informasi dalam mendukung proses bisnis pada PT. Pos Indonesia merupakan bagian yang sangat diperhatikan oleh para pucuk pimpinan. Berdasarkan tanggung jawabnya, pengelolaan teknologi informasi di PT. Pos Indonesia dapat dilihat pada Tabel 1 berikut ini:

Tabel 1. Domain Keputusan IT

\begin{tabular}{|c|l|l|}
\hline No. & Domain Keputusan & Tanggung Jawab \\
\hline 1 & IT Principle & Divisi Perencanaan Teknologi \\
\hline 2 & IT Architecture & Divisi Perencanaan Teknologi \\
\hline 3 & IT Infrastructure Strategic & Divisi Operasional Teknologi \\
\hline 4 & $\begin{array}{l}\text { Business Application } \\
\text { Needs }\end{array}$ & $\begin{array}{l}\text { Divisi Komersial, Divisi Keuangan, Divisi Pengiriman } \\
\text { Logistik }\end{array}$ \\
\hline 5 & IT Investment & $\begin{array}{l}\text { Divisi Operasional Teknologi, Divisi Perencanaan } \\
\text { Teknologi }\end{array}$ \\
\hline
\end{tabular}

Berdasarkan Tabel 1 diatas, makna dari setiap domain keputusan dapat dijelaskan sebagai berikut:

1. IT Principle, artinya menjelaskan bagaimana prinsip-prinsip teknologi informasi dapat mengadopsi prinsip-prinsip bisnis, sehingga membantu dalam proses pengambilan keputusan TI.

2. IT Architecture, menggambarkan bisnis inti perusahaan.

3. IT Infrastructure Strategic, menjelaskan bahwa perusahaan akan menentukan layanan infrastruktur apa yang paling penting untuk mencapai tujuan strategis perusahaan.

4. Business Application Needs, menjelaskan bahwa ada peluang pasar dan proses bisnis perusahaan.

5. IT Investment, menjelaskan bahwa perusahaan menentukan bahwa ada perubahan atau perbaikan pada proses-proses yang ada di perusahaan yang dianggap sangat strategis bagi perusahaan.

Mengadopsi dari Archetype Governance (Business Monarchy, IT Monarchy, Federal, Duopoly IT, dan Feudal), dan dari deskripsi ruang lingkup bisnis dan domain keputusan TI pada PT. Pos Indonesia di atas, maka kita dapat menggambarkan Matriks Tata Kelola TI sebagai berikut:

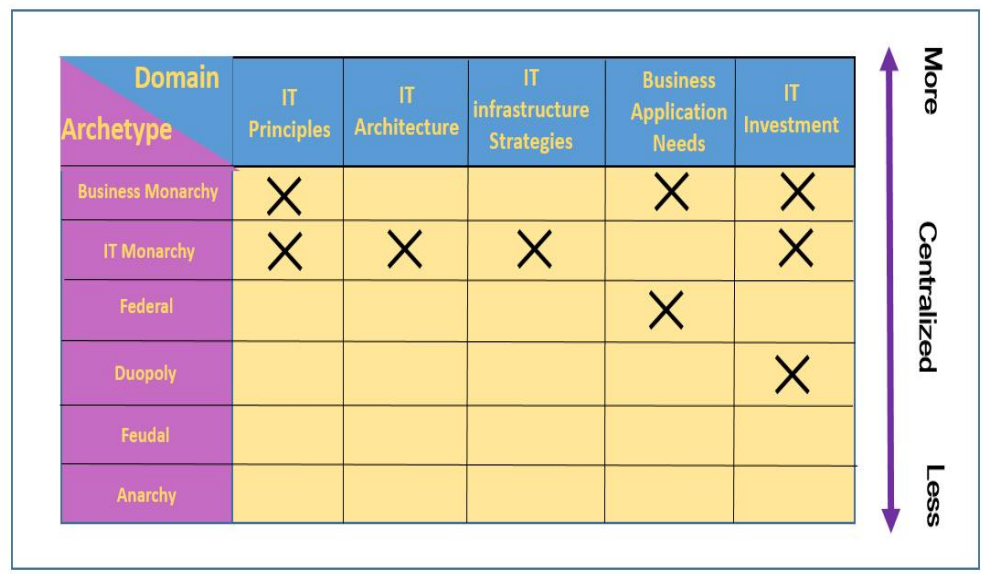

Gambar 2. Matriks Tata Kelola TI PT. Pos Indonesian 
Berdasarkan Gambar 2 di atas, dapat dilihat bahwa tata kelola TI yang diterapkan pada PT. Pos Indonesia adalah Hibrid, hal ini ini dapat dilihat dengan keputusan bahwa "Prinsip TI, Arsitektur TI, Strategi Infrastruktur TI dan Investasi TI lebih mungkin untuk dikelola oleh divisi teknologi, sedangkan untuk aplikasi bisnis perlu lebih menyebar ke berbagai divisi'”. Regulasi terkait Tata Kelola TI yang bersifat Hibrid sangat dianjurkan, karena PT. Pos Indonesia telah mulai memperluas cakupan bisnisnya. Dengan banyak unit bisnis yang memerlukan manajemen TI, tidak tepat untuk diterapkan Terpusat, karena jika perusahaan memiliki kantor di setiap unit bisnisnya, akan kurang realistis untuk mengatur pembelian melalui kantor pusat.

\section{B. Pengukuran Kinerja Tata Kelola TI pada PT. Pos Indonesia}

Alat yang digunakan dalam mengukur kinerja tata kelola TI saat ini menggunakan teknik penyebaran kuesioner untuk mengukur capaian indikatornya, yaitu: seberapa pentingkah hasil tata kelola TI, dan apa pengaruh tata kelola TI dalam bisnis [2]. Format kuesioner yang digunakan ditunjukan seperti pada Gambar 3 di bawah ini:

Assess Your IT Governance Performance

\section{Questionnaire}

Instructions :

Fill in the box next to each questionnaire below with a numeric code as shown next to this

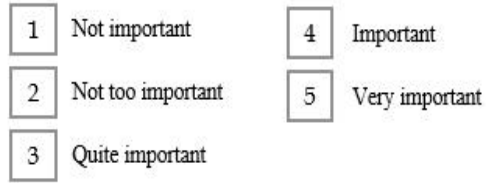

- Judgment -

1 How important are the following outcomes of your IT governance on scale from 1 (not important) to 5 (very important)

1. Cost effective use of IT

2. Effective use of IT for growth

3. Effective use of IT for asset utilization

4. Effective use of IT for business flexibility

Instructions :

Fill in the box next to each questionnaire below with a numeric code as shown next to this

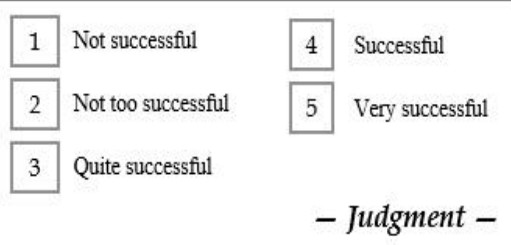

What is the influence of the IT governance in your business on the following measures of success on scale from 1 (not successful) to 5 (very successful)

\begin{tabular}{ll}
\hline 1. & Cost effective use of IT \\
\hline 2. & Effective use of IT for growth \\
3. & Effective use of IT for asset utilization \\
\hline 4. & Effective use of IT for business flexibility
\end{tabular}

Gambar 3. Kuesioner untuk Mengakses Kinerja Tata Kelola TI 
Metode kuesioner sangat tepat digunakan dalam mengumpulkan data dari responden, alasannya adalah karena kuesioner lebih sederhana dan lebih umum sifatnya [14]. Responden dalam penelitian ini adalah tingkat kepemimpinan unit di lingkungan PT. Pos Indonesia. Berdasarkan hasil pengolahan data kuesioner tentang Nilai Kinerja IT Governance di PT. Pos Indonesia dapat ditunjukkan pada Tabel 2 dan 3 di bawah ini. Jumlah responden adalah 36 responden.

Tabel 2. Hasil Kuesioner Terhadap Kinerja Tata Kelola TI (responden 1-20)

\begin{tabular}{|c|c|c|c|c|c|c|c|c|c|c|c|c|c|c|c|c|c|c|c|c|c|c|}
\hline No. & & Description & \multicolumn{20}{|c|}{ Responden } \\
\hline \multirow[t]{5}{*}{1.} & & $\begin{array}{l}\text { How important are the following outcomes of } \\
\text { your IT governance on a scale from } 1 \text { (not } \\
\text { important) to } 5 \text { (very important)? }\end{array}$ & 1 & 2 & 3 & 4 & 5 & 6 & 7 & 8 & 9 & 10 & 11 & 12 & 13 & 14 & 15 & 16 & 17 & 18 & 19 & 20 \\
\hline & a. & Cost effective use of IT & 4 & 5 & 4 & 5 & 4 & 4 & 5 & 3 & 4 & 4 & 4 & 4 & 5 & 5 & 2 & 4 & 5 & 5 & 4 & 4 \\
\hline & b. & Effective use of IT for growth & 5 & 5 & 5 & 4 & 5 & 5 & 4 & 5 & 4 & 5 & 5 & 4 & 5 & 5 & 3 & 4 & 5 & 5 & 5 & 5 \\
\hline & c. & Effective use of IT for asset utilization & 4 & 5 & 5 & 5 & 5 & 5 & 5 & 4 & 4 & 4 & 4 & 3 & 5 & 5 & 3 & 4 & 5 & 5 & 4 & 5 \\
\hline & d. & effective use of IT for business flexibility & 5 & 5 & 4 & 4 & 5 & 5 & 5 & 4 & 5 & 5 & 4 & 3 & 5 & 5 & 3 & 4 & 5 & 5 & 4 & 5 \\
\hline \multirow[t]{5}{*}{2.} & \multicolumn{2}{|r|}{$\begin{array}{c}\text { What is the influence of the IT governance in your } \\
\text { business on the following measures of success on } \\
\text { a scale from } 1 \text { (not successful) to } 5 \text { (very } \\
\text { successful)? }\end{array}$} & 1 & 2 & 3 & 4 & 5 & 6 & 7 & 8 & 9 & 10 & 11 & 12 & 13 & 14 & 15 & 16 & 17 & 18 & 19 & 20 \\
\hline & $a_{1}$ & Cost effective use of IT & 4 & 1 & 2 & 4 & 4 & 4 & 3 & 3 & 3 & 3 & 2 & 3 & 3 & 2 & 2 & 3 & 3 & 4 & 4 & 4 \\
\hline & b. & Effective use of IT for growth & 5 & 1 & 2 & 4 & 4 & 4 & 3 & 5 & 3 & 3 & 2 & 3 & 4 & 2 & 2 & 3 & 3 & 4 & 4 & 4 \\
\hline & c. & Effective use of IT for asset utilization & 4 & 1 & 2 & 4 & 4 & 4 & 3 & 3 & 4 & 3 & 1 & 3 & 4 & 2 & 2 & 3 & 3 & 4 & 4 & 4 \\
\hline & d. & effective use of IT for business flexibility & 5 & 1 & 2 & 4 & 4 & 5 & 3 & 4 & 4 & 3 & 1 & 3 & 5 & 2 & 2 & 3 & 3 & 4 & 4 & 5 \\
\hline
\end{tabular}

Tabel 3. Hasil Kuesioner Terhadap Kinerja Tata Kelola TI (Responden 21-36)

\begin{tabular}{|c|c|c|c|c|c|c|c|c|c|c|c|c|c|c|c|c|c|c|}
\hline \multirow{3}{*}{1.} & \multirow{2}{*}{\multicolumn{2}{|c|}{$\begin{array}{c}\text { Description } \\
\text { How important are the } \\
\text { following outcomes of your } \\
\text { IT governance on a scale } \\
\text { from } 1 \text { (not important) to } 5 \\
\text { (very important)? }\end{array}$}} & \multicolumn{16}{|c|}{ Responden } \\
\hline & & & 21 & 22 & 23 & 24 & 25 & 26 & 27 & 28 & 29 & 30 & 31 & 32 & 33 & 34 & 35 & 36 \\
\hline & a. & Cost effective use of IT & 4 & 4 & 1 & 5 & 4 & 4 & 4 & 5 & 5 & 3 & 5 & 3 & 4 & 4 & 4 & 4 \\
\hline & b. & $\begin{array}{l}\text { Effective use of IT for } \\
\text { growth }\end{array}$ & 4 & 4 & 2 & 5 & 5 & 4 & 4 & 5 & 4 & 4 & 5 & 5 & 5 & 4 & 3 & 4 \\
\hline & c. & $\begin{array}{l}\text { Effective use of IT for } \\
\text { asset utilization }\end{array}$ & 4 & 5 & 1 & 5 & 4 & 4 & 4 & 4 & 4 & 3 & 4 & 3 & 4 & 3 & 4 & 5 \\
\hline & d. & $\begin{array}{l}\text { effective use of IT for } \\
\text { business flexibility }\end{array}$ & 4 & 5 & 1 & 5 & 4 & 5 & 4 & 4 & 4 & 4 & 4 & 5 & 5 & 5 & 4 & 4 \\
\hline \multirow[t]{5}{*}{2.} & \multicolumn{2}{|c|}{$\begin{array}{l}\text { What is the influence of the } \\
\text { IT governance in your } \\
\text { business on the following } \\
\text { measures of success on a } \\
\text { scale from } 1 \text { (not successful) } \\
\text { to } 5 \text { (very successful)? }\end{array}$} & 21 & 22 & 23 & 24 & 25 & 26 & 27 & 28 & 29 & 30 & 31 & 32 & 33 & 34 & 35 & 36 \\
\hline & a. & Cost effective use of IT & 4 & 5 & 1 & 2 & 4 & 4 & 4 & 4 & 4 & 3 & 3 & 3 & 3 & 2 & 3 & 3 \\
\hline & b. & $\begin{array}{l}\text { Effective use of IT for } \\
\text { growth }\end{array}$ & 4 & 5 & 2 & 2 & 4 & 4 & 4 & 4 & 4 & 4 & 3 & 5 & 4 & 2 & 4 & 3 \\
\hline & c. & $\begin{array}{l}\text { Effective use of IT for } \\
\text { asset utilization }\end{array}$ & 4 & 5 & 1 & 3 & 4 & 4 & 4 & 4 & 4 & 4 & 3 & 3 & 3 & 1 & 4 & 3 \\
\hline & d. & $\begin{array}{l}\text { effective use of IT for } \\
\text { business flexibility }\end{array}$ & 4 & 5 & 1 & 1 & 4 & 4 & 4 & 4 & 4 & 4 & 3 & 5 & 3 & 1 & 3 & 3 \\
\hline
\end{tabular}


Berdasarkan hasil pengolahan data kuesioner (hasil pengolahan data dari Tabel 2 dan Tabel 3), selanjutnya dapat dihitung Nilai Kinerja Tata Kelola TI di PT. Pos Indonesia, seperti ditunjukkan pada Tabel 4 di bawah ini:

Tabel 4. Kinerja Tata Kelola TI PT. Pos Indonesia

\begin{tabular}{|c|c|c|c|c|c|c|}
\hline No. & Deskripsi & $\mathrm{P}^{\mathrm{a}}$ & & $\mathrm{P}^{\mathrm{b}}$ & & \\
\hline a. & Cost effective use of IT & 4.08 & $\mathrm{X}$ & 3.1 & $=$ & 12.82 \\
\hline b. & Effective use of IT for growth & 4.44 & $\mathrm{X}$ & 3.4 & $=$ & 15.19 \\
\hline c. & Effective use of IT for asset utilization & 4.17 & $\mathrm{X}$ & 3.2 & $=$ & 13.43 \\
\hline d. & $\begin{array}{l}\text { Effective use of IT for business } \\
\text { flexibility }\end{array}$ & 4.36 & $\mathrm{X}$ & 3.3 & $=$ & 14.54 \\
\hline & Total1 & 17.1 & & & & 55.97 \\
\hline \multicolumn{7}{|c|}{ Perhitungan kinerja tata kelola } \\
\hline \multicolumn{2}{|c|}{$($ Total1 $\times 100) /(5 \times$ Total 2$)$} & \multicolumn{5}{|l|}{65.6} \\
\hline
\end{tabular}

Berdasarkan nilai kinerja tata kelola TI yang didapat seperti padaTabel 4 di atas, jika kita visualisasikan dalam bentuk prosentase, maka hasilnya dapat dilihat seperti ditunjukkan pada Gambar 4 berikut ini:

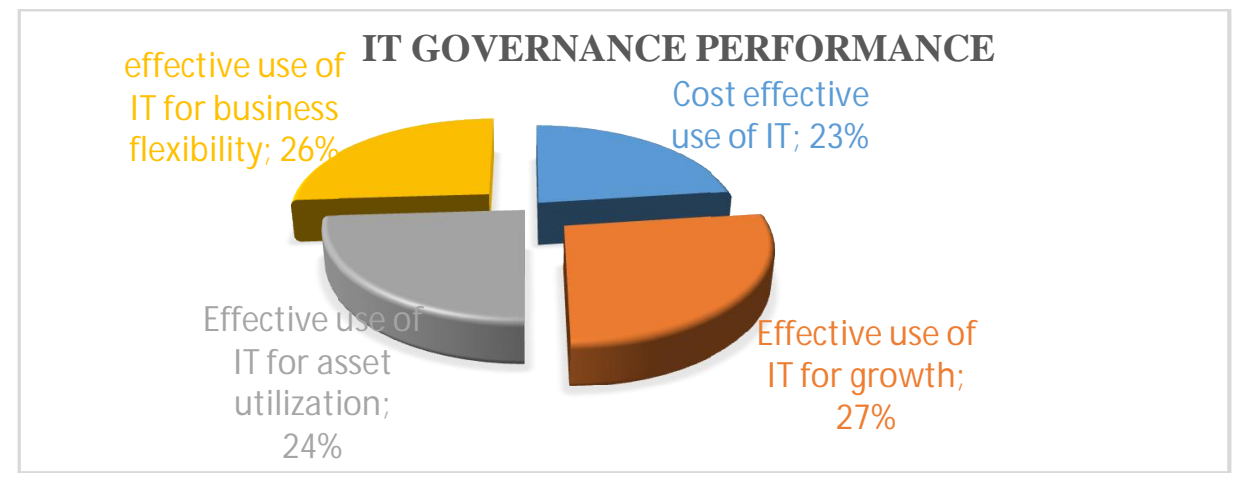

Gambar 4. Prosentase Nilai Kinerja Tata Kelola TI

Berdasarkan nilai kinerja tata kelola TI yang sudah ada, selanjutnya kita dapat menentukan posisi nilai kinerja tata kelola TI di PT. Pos Indonesia saat ini dengan menggunakan skala pengukuran tata kelola TI seperti ditunjukkan pada Gambar 5 di bawah ini:

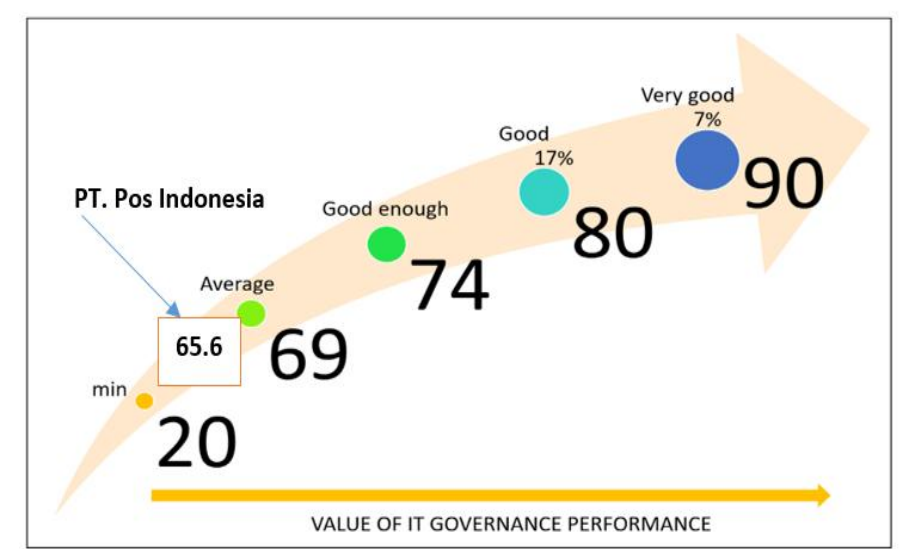

Gambar 5. Posisi Nilai Kinerja Tata Kelola TI PT. Pos Indonesia Saat Ini [2] 
Berdasarkan nilai rata-rata kinerja tata kelola ditetapkan berada di angka 69 (dari Peter Wiell and Jeanne W. Ross, 2004) yang terdapat dalam [1]. Sehingga nilai rata-rata kinerja tata kelola di PT. Pos Indonesia seperti terlihat pada Gambar 5, maka itu menunjukkan bahwa PT. Pos Indonesia (kondisi saat ini) berada diantara nilai minimum (20) dan nilai rata-rata (69), lebih tepatnya saat ini kinerja tata kelola PT. Pos Indonesia berada pada posisi di bawah ratarata dengan nilai 65,6.Nilai ini didapat dengan kondisi bahwa responden rata-rata memilih nilai bobot 4(penting) untuk pertanyaan (1), dan rata-rata memilih nilai bobot 3(cukup berhasil) untuk pertanyaan (2). Data hasil kuesioner dari responden lengkap ditunjukkan pada Tabel 2 dan 3 di atas.

\section{KESIMPULAN}

Hasil penelitian ini dapat disimpulkan sebagai berikut:

1. Tata Kelola TI yang diterapkan di PT. Pos Indonesia adalah Hibrid, ini dapat dilihat dari keputusan tentang IT Principle, IT Architecture, IT Infrastructure Strategiesdan IT Investmentyang lebih mungkin dikelola oleh Divisi Teknologi, sedangkan untuk aplikasi bisnis, kebutuhan lebih tersebar ke berbagai divisi.

2. Dari hasil perhitungan nilai kinerja tata kelola TI pada PT. Pos Indonesia saat ini berada di bawah nilai rata-rata dengan nilai 65,6. Dari empat bidang / target yang menjadi bobot kepentingan perusahaan, bidang-bidang yang menjadi kelemahan PT. Pos Indonesia berada pada Cost Effective use of IT sebesar 12,82 atau 23\% dibandingkan satu sama lain, Effective use of IT for growth (27\%), Effective use of IT for asset utilization (24\%), danEffective use of IT for business flexibility (26\%).

Keterbatasan dalam penelitian ini adalah:

1. Instrumen yang digunakan dalam pengukuran nilai kinerja tata kelola TI yang diterapkan di PT. Pos Indonesia ini hanya terbatas pada 2 (dua) indikator, yaitu: seberapa pentingkah hasil tata kelola TI, dan apa pengaruh tata kelola TI dalam bisnis, hal ini masih dirasa kurang maksimal untuk menetapkan nilai kinerja tata kelola TI perusahaan. Untuk itu disarankan pada peneliti-peneliti selanjutnya dapat merumuskan indikator pengukuran kinerja tata kelola TI yang lebih lengkap lagi, yang bisa mencakup segala aspek bisnis baik finansial maupun nonfinansial.

2. Responden yang digunakan oleh peneliti hanya pada 1(satu) perusahaan/bisnis logistik saja dengan jumlah responden dari beberapa manajemen puncak dari unit-unit yang ada. Sebaiknya bisa menggunakan responden yang lebih banyak lagi dengan cakupan secara global dari industri logistik di Indonesia.

\section{UCAPAN TERIMA KASIH}

Penulis ingin mengucapkan terima kasih atas kritik, saran dan masukan dari makalah ini. Komentar dari pembaca sangat berguna dalam perbaikan substantif makalah ini.Terima kasih kami yang tulus kepada Politeknik Pos Indonesia dan PT. Pos Indonesia dengan dukungan untuk menyelesaikan penelitian ini. 


\section{DAFTAR PUSTAKA}

[1] R. S. De Almeida, 2013, “Implementing IT Governance," Inf. Syst. Comput. Eng., No. November

[2] S. C. B. Barbosa, I. A. Rodello, and S. I. D. de Padua, 2014, "Performance Measurement of Information Technology Governance in Brazilian Financial Institutions," JISTEM - J. Inf. Syst. Technol. Manag., Vol. 11, No. 2, pp. 397-414.

[3] R. Pereira and M. M. da Silva, 2012, "A Literature Review: Guidelines and Contingency Factor for IT Governance," Eur. Mediterr. Middle East. Conf. Inf. Syst. 2012, Vol. 2012, pp. $342-360$.

[4] G. L. Lunardi, A. C. G. Maçada, and J. L. Becker, 2014, "IT Governance Effectiveness and its Antecedents : an Empirical Examination in Brazilian Firms," 47th Hawaii Int. Conf. Syst. Sci. IT.

[5] M. Clarke, 2010, "IT Governance Design: An Application of Problem Oriented Engineering to Enterprise Architecture, TOGAF and SOA Development,"

[6] Y. Karayilan, 2013, "Operational Level IT Governance Model for Partnering and Value Co-Creation in an Ecosystem," Helsinki Metrop. Univ. Appl. Sci., No. May.

[7] R. Hadad, E. Darwiyanto, and I. L. Sardi, 2017, "Penilaian Penerapan Tata Kelola Teknologi Informasi Di Universitas Telkom Menggunakan Framework Cobit 5 Information Technology Governance Planning For Telkom University Using Cobit 5," eProceeding Eng., Vol. 4, No. 2, pp. 3166-3172.

[8] A. Tabach, 2013, "IT Governance Impact on Business Unit Performance," Concordia Univ., No. December.

[9] A. Khallaf, 2012, "Information Technology Investments and Nonfinancial Measures : A Research Framework," Account. Forum, Vol. 36, No. 2, pp. 109-121.

[10] Adityawarman, "Pengukuran Tingkat Kematangan Penyelarasan Strategi Teknologi Informasi Terhadap Strategi Bisnis Analisis Menggunakan Framework COBIT 4.1,” J. Akunt. Audit., Vol. 8, No. 2, pp. 166-177, 2012.

[11] K. Ahmad and S. M. Zabri, "The Application of Non-Financial Performance Measurement in Malaysian Manufacturing Firms," Procedia Econ. Financ., Vol. 35, No. October 2015, pp. 476-484, 2016.

[12] Y. Yuliansyah and M. S. A. Razimi, "Non-financial Performance Measures and Managerial Performance: The Mediation Role of Innovation in an Indonesian Stock Exchange-Listed Organization," Probl. Perspect. Manag., Vol. 13, No. 4, pp. 135-144, 2015.

[13] P. Zhang, K. Zhao, and R. L. Kumar, "Impact of IT Governance and IT Capability on Firm Performance," Inf. Syst. Manag., Vol. 33, No. 4, pp. 357-373, 2016. 
[14] R. Vaziri and M. Mohsenzadeh, “A Questionnaire - Based Data Quality,” Vol. 4, No. 2, pp. 55-68, 2012. 